Dikirim:

9 Mei 2018

Diterima:

25 Januari 2019
Research Article

\section{Strategi monitoring kepatuhan penggunaan antiretroviral pre-exposure prophilaxis pada pasangan serodiscordant}

Monitoring strategy of antiretroviral pre-exposure prophylaxis adherence among serodiscordant couple

Ni Kadek Diah Purnamayanti ${ }^{1}$, Nurma Yuni Pari Usemahu ${ }^{2}$, Fatih Haris $\mathrm{M}^{3}$, Marina Kristi Layun $\mathrm{R}^{4}$

\section{Abstract}

Antiretroviral pre-exposure prophylaxis (PrEP) has been recommended as HIV prevention but poor medical adherence can cause suboptimal therapy. This study explored the strategies of monitoring PrEP adherence among the serodiscordant couples. This systematic review based on 4 data bases (Scopus, Pubmed, Ebsco and Sage Journal), included clinical trial studies articles between 2013-2018, in English, and available in full-text. Papers, which not met the inclusion criteria, will be excluded. Keywords used in this study are 'serodiscordant couple' AND 'method' OR 'strategy' OR 'approach' AND 'preexposure prophylaxis intention' OR 'pre-exposure prophylaxis adherence'. This study discovered various strategies applied based on the type of delivering process, the variance of dose, and variance of preference of the couple. Preference of PrEP dose and type of application related to heterosexual or homosexual orientation and their social commitment. The paper explains the advantage of $\mathrm{M}$-health and biomarker level monitoring.

Keywords: adherence; pre-exposure prophylaxis; serodiscordant couple 


\section{PENDAHULUAN}

Organisasi Kesehatan Dunia (WHO) menyebut 36,7 juta orang terinfeksi HIV dan 1,1 juta orang meninggal akibat AIDS. Beragam metode pencegahan telah dilakukan untuk mengurangi penularan HIV seperti penggunaan kondom pria dan wanita, pencegahan penularan HIV dari ibu-ke-bayi atau PMTCT (1).

Saat ini terdapat metode untuk memperlambat perkembangan HIV menjadi AIDS melalui terapi antiretroviral. Cara ini menggunakan pendekatan pre exposure profilaksis (PrEP) untuk membatasi penularan infeksi HIV (2). Pre exposure profilaksis melalui pemberian pil antiretroviral (ARV) setiap hari kepada orang dengan HIV negatif (3).

Organisasi Kesehatan Dunia (WHO) telah membuat sebuah laporan yang menawarkan bimbingan untuk pasangan serodiskordan, atau pasangan yang memiliki status HIV positif dan negatif. WHO merekomendasikan pasangan serodiskordan harus menerima terapi antiretroviral (ART) untuk pencegahan HIV. Upaya pencegahan pasangan serodiskordan pertama-tama harus mengikuti rekomendasi yang ditetapkan dalam Pedoman tes dan konseling HIV, termasuk terapi antiretroviral untuk pengobatan dan pencegahan pada pasangan serodiskordan. Pedoman ini merekomendasikan penggunaan pengobatan dini dengan antiretroviral untuk pasangan yang terinfeksi untuk mengurangi kemungkinan penularan HIV (4). Hal ini dibutuhkan adanya pengetahuan serta adherence (kepatuhan) pasien yang menjalani terapi (5)

Adherence (kepatuhan) pasien yang menjalaani terapi pre exposure profilaxis harus sesuai dengan petunjuk pada resep yang diberikan petugas kesehatan bagi pasien yang menjalani terapi meliputi ketepatan dalam waktu, jumlah, dosis yang tepat dalam mengkonsumsi obat. Ketidakpatuhan dalam pelaksanaan terapi akan menurunkan efektivitas kerja obat ARV bahkan meningkatkan resistensi virus dalam tubuh. Kepatuhan terhadap penggunaan ARV sangat bermanfaat untuk menekan berkembangnya penyakit HIV, mengurangi risiko resistensi obat, meningkatkan kualitas hidup, serta penurunan risiko transmisi penyakit HIV (6).

\section{METODE}

Penelitian ini menggunakan desain integrative research review dengan prosedur tahapan studi pustaka yang terdiri dari lima tahapan (7). Tahapan studi meliputi perumusan masalah, pengumpulan data berupa literature, evaluasi data, analisis data, dan presentasi hasil. Rumusan masalah dalam studi ini adalah mengeksplorasi pendekatan yang paling efektif dalam memberikan intervensi PrEP dan melakukan monitoring kepatuhan pada pasangan serodiscordant. Penelusuran dilakukan pada 4 mesin pencari online yaitu Scopus, Pubmed, Ebsco dan Sage Journal. Kriteria inklusi dalam studi ini adalah artikel yang dipublikasi dalam rentang 2012-2018, tertulis dalam Bahasa Inggris, tersedia dan dapat diakses keseluruhan artikel. Desain penelitian yang dipilih melibatkan clinical trial atau studi yang telah diuji coba dalam bentuk pilot study, kuasi eksperimen, dan randomized controlled trial (RCT). Evaluasi kualitas evidence berdasarkan Crowe Critical Appraisal Tool 2013 (8). Evaluasi literatur pada studi ini menggunakan JADAD score (9). Seleksi artikel sesuai dengan tahapan ditampilkan dalam PRISMA flow diagram pada Gambar $1(10)$.

\section{HASIL DAN BAHASAN}

Tabel 1 adalah hasil ekstraksi data yang mencakup penulis, protokol intervensi, dan outcome terkait kepatuhan penggunaan PrEP yang dirangkum pada Tabel 1. Studi ini menggunakan lima (5) original artikel kuantitatif yang merupakan studi dengan desain Randomize Control Trial (RCT) dan kuasi eksperimen serta pilot study. Penelitian RCT $(11,12)$, penelitian pilot study Mayer et al., (13) dan desain kuasi eksperimen (14). Hasil dari literature review menemukan kepatuhan pada dua discordant couple yang berbeda. Pertama yaitu discordant couple yang terdiri dari pasangan laki-laki dan perempuan, kedua yaitu discordant couple sesama jenis atau lebih dikenal dengan "Men who Have sex with Men” (MSM). Metode atau pendekatan yang diperoleh dari hasil tinjauan literatur antara lain, Pelaporan mandiri $(12,14)$, biomarker kadar tenofovir dalam plasma darah (13); konseling, jumlah tablet yang dikembalikan saat ke rumah sakit (15).

\section{Tenofovirs sebagai biomarker kepatuhan PrEP}

Review ini menggunakan biomarker kadar Tenofovir dalam darah untuk menilai kepatuhan. Kadar plasma tenofovir sama dengan atau lebih dari $52.0 \mathrm{mg} / \mathrm{mL}$ menunjukkan konsumsi rutin harian. Perbandingan kepatuhan PrEP secara m-Health menggunakan Wisepill, menunjukkan perbedaan signifikan antara kelompok kontrol dan intervensi. Namun, kepatuhan berdasarkan pengukuran level Tenofovir plasma tidak ada perbedaan signifikan antara kelompok kontrol dan intervensi (13).

\section{MHealth sebagai bentuk monitoring kepatuhan}

M-Health merupakan salah satu pendekatan yang dapat digunakan untuk menilai kepatuhan Pre Exposure Prophylaxis (PrEP). Jenis layanan m-health yang direview pada penelitian ini adalah SMS, Medication Event Monitoring System (MEMS), Wisepill. Penggunaan harian PrEP dilaporkan melalui SMS oleh partisipan kepada peneliti mengenai konsumsi PrEP per oral/rektal/RAI 


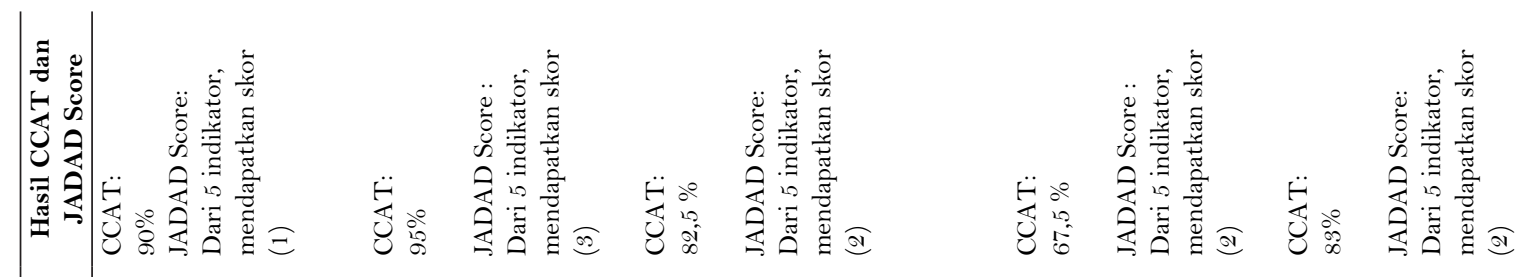

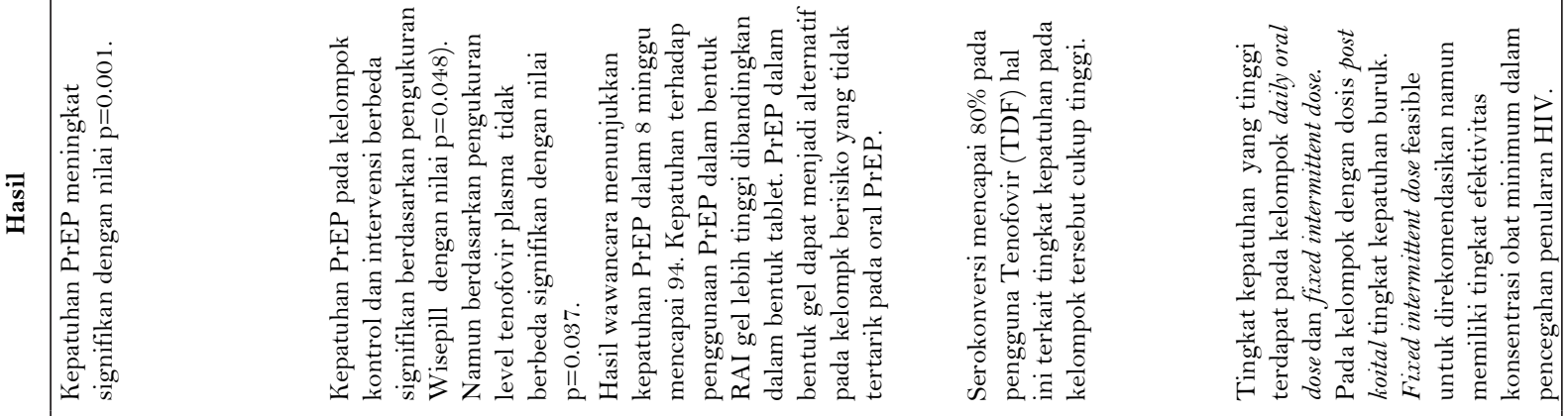

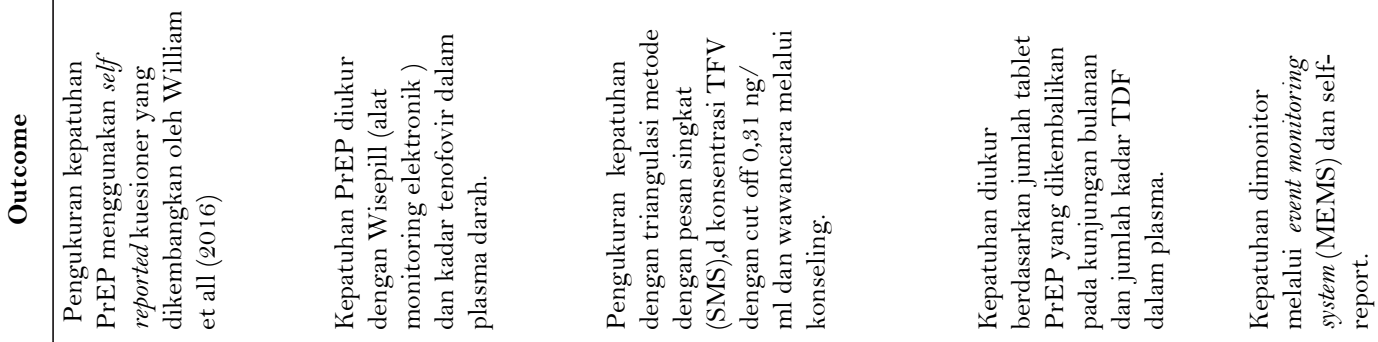

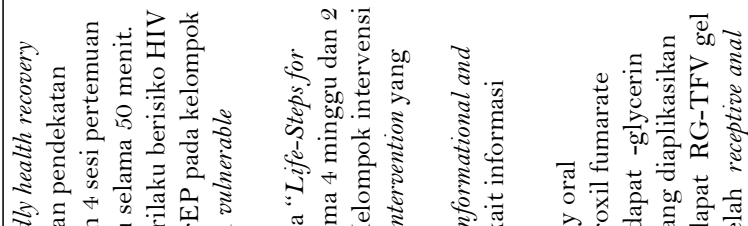

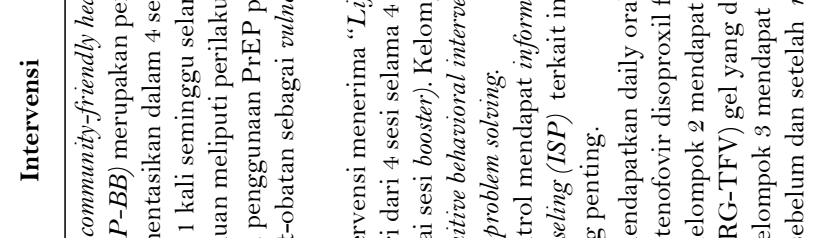

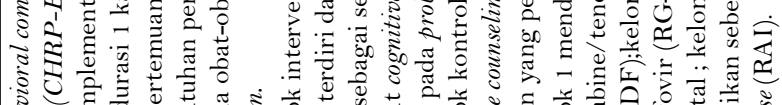

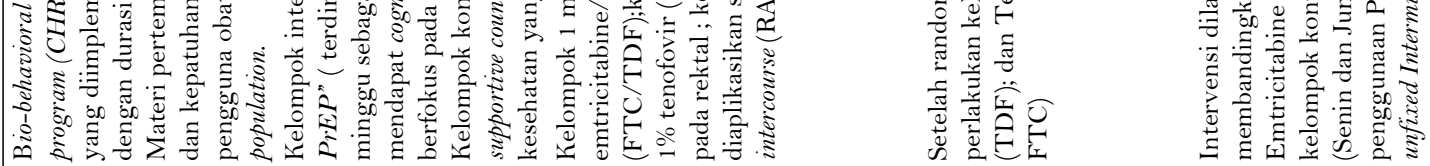

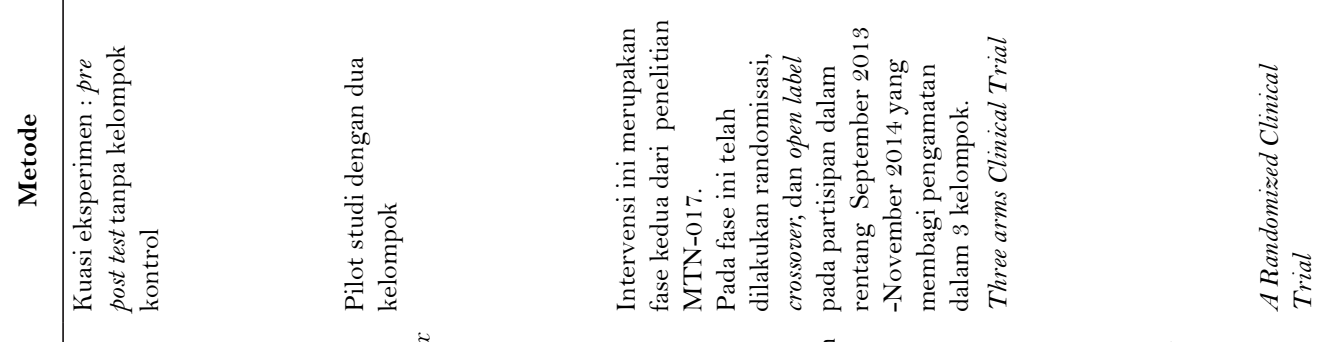

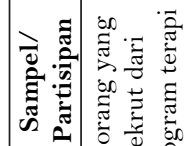

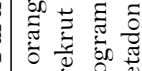

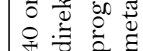

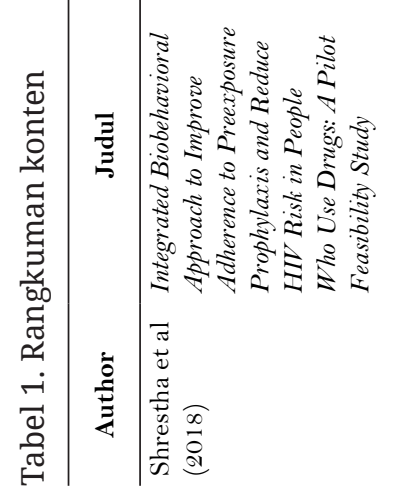

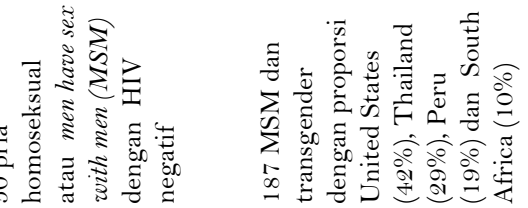
Why

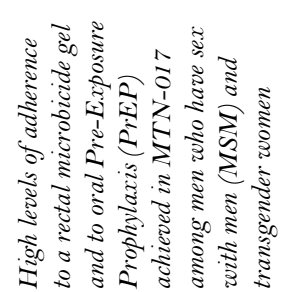

离

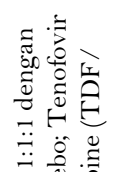

$\frac{\pi}{3} \frac{0}{0}$

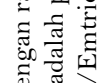

要

을

要

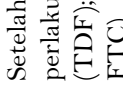

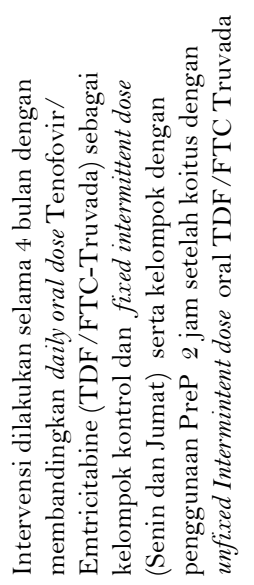

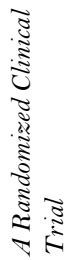

WIIn

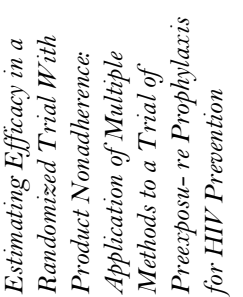

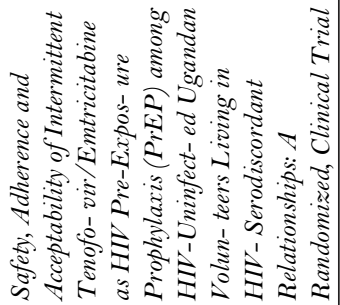

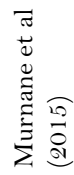

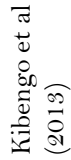


Tabel 2. JADAD Score

\begin{tabular}{|c|c|c|c|c|c|}
\hline \multirow{2}{*}{$\begin{array}{c}\text { Kualifikasi } \\
\text { Berdasarkan JADAD } \\
\text { Score }\end{array}$} & \multicolumn{2}{|c|}{ Randomisasi } & \multicolumn{2}{|c|}{ Blinding } & \multirow{2}{*}{$\begin{array}{c}\text { Withdrowal } \\
\text { Jumlah dan alasan } \\
\text { withdrawal dijelaskan }\end{array}$} \\
\hline & $\begin{array}{l}\text { Dilakukan } \\
\text { randomisasi }\end{array}$ & $\begin{array}{c}\text { Metode randomisasi } \\
\text { dijelaskan }\end{array}$ & Dilakukan blinding & $\begin{array}{c}\text { Teknik blinding } \\
\text { dijelaskan }\end{array}$ & \\
\hline Shrestha et al (2018) & - & - & - & - & $\sqrt{ }$ \\
\hline Mayer et all (2016) & $\sqrt{ }$ & $\sqrt{ }$ & - & - & $\sqrt{ }$ \\
\hline Dieguez et al (2016) & $\sqrt{ }$ & - & - & - & $\sqrt{ }$ \\
\hline Murnane et al (2015) & $\sqrt{ }$ & - & $\sqrt{ }$ & - & - \\
\hline Kibengo et al (2013) & $\sqrt{ }$ & - & $\sqrt{ }$ & - & - \\
\hline
\end{tabular}

*Keterangan : tanda $(\sqrt{ })$ berarti dijelaskan pada artikel; tanda (-) tidak dijelaskan pada artikel.

$(11,13)$. SMS berfungsi sebagai pengingat konsumsi obat dan sebagai pendekatan yang berpusat pada klien untuk meningkatkan kepatuhan penggunaan obat. Peneliti akan menghubungi klien jika dalam 48 jam klien tidak memberikan informasi penggunaan harian. MEMS merupakan sistem pemantauan untuk menilai kepatuhan secara objektif dengan merekam kuantitas "membuka dan menutupnya” penutup botol profilaksis melalui microchip yang sebelumnya telah ditempatkan pada penutup botol (12). Rekaman yang sudah dihasilkan akan dikalkulasi selama satu bulan. Hampir serupa dengan MEMS, Wisepill (13) dirancang pemantauan kepatuhan real-time. Wisepill adalah perangkat penyimpanan pil elektronik yang memungkinkan pemantauan kepatuhan real-time dengan mengirim data dan cap setiap kali dibuka dengan menggunakan Subscriber Identity Module (SIM) card.

\section{Pelaporan mandiri sebagai pendekatan kepatuhan}

Pelaporan mandiri menjadi salah satu cara sederhana untuk melihat kepatuhan pasien, saat monitoring kepatuhan tidak dapat dilakukan secara real-time. Pelaporan mandiri (12) dengan pencatatan dosis dan frekuensi penggunaan PreEP mempunyai kepatuhan yang tinggi terdapat pada kelompok daily oral dose dan fixed intermittent dose. Shrestha et al (2018) melakukan Pengukuran kepatuhan PrEP menggunakan self reported questionnaire (PrEP adherence, drug use, sexual risk behaviorisme) menunjukan kepatuhan penggunaan PrEP meningkat signifikan (14).

\section{Gel Microbisida MTN 017}

Gel tenofovir vaginal dapat mengurangi risiko infeksi HIV sekitar 40\% oleh CAPRISA 004 tetapi formulasi gel tersebut tidak cocok dipakai (15). MTN dirumuskan penggunaan gel yang mengandung lebih sedikit gliserin lebih dapat ditolerir dan lebih dapat diterima. MTN-017 adalah fase 2 yang dilakukan randomisasi crossover dengan subyek peserta antara September 2013 dan November 2014 dengan membandingkan 1) emtricitabine oral harian/tenofovir disoproxil fumarate (FTC/TDF); 2) penggunaan gliserin tereduksi $1 \%$ tenofovir (RG-TFV) setiap hari gel dioleskan secara rektal; dan 3) gel RGTFV diterapkan sebelum dan sesudah hubungan seks anal (RAI). Penelitian MTN-017 melibatkan 187 gay dan transgender di Peru (19\%), Afrika Selatan (10\%), Thailand (29\%), dan AS (42\%) termasuk Puerto Rico. MTN-017 meningkatkan level keamanan dan penerimaan mikrobisida gel di anus, dibandingkan penggunaan Truvada. Mikrobisida gel dengan tenofovir 1\% dapat mengurangi risiko infeksi HIV selama seks vaginal maupun rektal atau anal.

Pada MTN-017 juga terdapat follow up melalui pesan singkat (SMS) untuk pelaporan kepatuhan serta terdapat interview dan konseling di dalamnya sebagai ukuran kepatuhan kualitatif yang diberikan kepada tim studi klinis dalam waktu dua minggu dari koleksi sampel. Lebih jauh lagi, penggunaan pesan SMS harian dapat berfungsi sebagai pengingat penggunaan produk. Juga, pendekatan kolaboratif, berpusat pada klien yang digunakan untuk dukungan kepatuhan dapat telah mempengaruhi kesediaan para peserta. MTN-017 mempunyai kelayakan kepatuhan yang tinggi dan potensi pencegahan HIV (11).

\section{Formulasi tenofovir baru dalam pencegahan HIV pasangan serocordiant}

Studi tentang PrEP oral harian diikuti oleh 4.747 pasangan HIV serocordiant (satu pasangan terdiri dari satu orang HIV positif dengan partner yang HIV negatif) di Kenya dan Uganda (Juli 2008-Juli 2011). Individu HIV yang tidak terinfeksi diacak untuk menerima tenofovir disoproxil fumarate (TDF), emtrici-tabine (TDF/FTC), atau plasebo dengan rasio 1:1:1. Seluruh individual diobservasi selama satu hingga 36 bulan. PrEP tenofovir mengurangi risiko infeksi sebesar $62 \%$ dan TDF/FTC sebesar 73\%. Terapi antiretroviral yang efektif dapat mengurangi risiko penularan HIV secara signifikan pada pasangan serocordiant dengan biaya yang terjangkau. Pada kunjungan berkala, pasangan HIV negatif diberikan uji serologi dan dinilai perilaku seksualnya di tiga bulan pertama (16).

\section{Kebaharuan, Limitasi, Rekomendasi}

Penggunaan m-health (MEMS dan Wisepill) memungkinkan pelaporan secara real-time. Meskipun demikian, ketidakakuratan menjadi kelemahan dari m-health dikarenakan peralatan yang beroperasi secara otomatis. MEMS menggunakan “membuka botol” sebagai standar kepatuhan mengkonsumsi obat. Hal tersebut dapat menjadi bias karena aktivitas membuka botol obat 
bukan berarti mengkonsumsi obat. Selain itu, pelaporan secara mandiri (self-report) dan penggunaan m-health (SMS) lebih sesuai diimplementasikan di Indonesia.

\section{SIMPULAN}

Angka penularan virus HIV meningkat setiap tahun. Berbagai upaya telah dilakukan untuk menekan angka penularan penyakit. Salah satu contohnya adalah konsumsi PrEP pada individu berisiko tinggi, seperti pasangan discordant dengan salah satu partner yang memiliki hasil negatif. Pendekatan berbasis CBT dianggap paling sesuai. Monitoring kepatuhan dapat memanfaatkan teknologi m-health seperti text reminder dan medical device monitoring. Keberhasilan pendekatan teknologi tersebut membutuhkan komitmen dan kepatuhan dalam implementasi. Peran petugas kesehatan, pasien, dan kerabat pasien diperlukan untuk kesuksesan program pencegahan tersebut.

\begin{abstract}
Abstrak
Pemberian profilaksis pra-pajanan retroviral (PrEP) telah direkomendasikan sebagai pencegahan HIV tetapi kepatuhan medis yang buruk dapat menyebabkan terapi suboptimal. Studi ini mengeksplorasi strategi pemantauan kepatuhan PrPP di antara pasangan serodiskordan. Tinjauan sistematis ini didasarkan pada 4 basis data (Scopus, Pubmed, Ebsco dan Sage Journal), termasuk artikel studi uji klinis antara 2013-2018, dalam bahasa Inggris, dan tersedia dalam teks lengkap. Artikel, yang tidak memenuhi kriteria inklusi, dikeluarkan. Kata kunci dalam penelitian ini adalah ‘serodiscordant couple’ AND ‘method' OR 'strategy' OR ‘approach’ AND 'pre-exposure prophylaxis intention' OR 'preexposure prophylaxis adherence'. Penelitian ini menemukan berbagai strategi yang diterapkan berdasarkan jenis proses pemberian, varian dosis, dan varian preferensi pasangan. Preferensi dosis PrEP dan jenis aplikasi yang terkait dengan orientasi heteroseksual atau homoseksual dan komitmen sosial mereka. Studi ini menjelaskan keuntungan dari pemantauan tingkat M-health dan biomarker.
\end{abstract}

Kata kunci: adherence; pre-exposure prophylaxis; serodiscordant couples 


\section{PUSTAKA}

1. Tetteh RA, Yankey BA, Nartey ET, Lartey M, Leufkens HGM, Dodoo ANO. Pre-Exposure Prophylaxis for HIV Prevention: Safety Concerns. Drug Saf. 2017;40(4):27383.

2. Couples FORS. Guidance on Pre-Exposure Oral Prophilaxis (PrEP) for Sediscordant Couples and Transgender Who have Sex with Man at High Risk of HIV July 2012. Leonardo. 2012;(July):106-106.

3. Centers for Disease Control and Prevention. Preexposure Prophylaxis for the Prevention of HIV Infection in the United States - 2014 Clinical Practice Guideline. Mmwr. 2014;1-67.

4. Elsasser J. April 2012. Public Relations Tactics. 2012;19(4):3.

5. Dima AL, Schweitzer AM, Amico KR, Wanless RS. The Information-Motivation-Behavioral Skills Model of ART Adherence in Romanian Young Adults. J HIV/ AIDS Soc Serv. 2013;12(3-4):274-93.

6. Russell C. An overview of the integrative research review. Prog Transplant [Internet]. 2005;15(1):8-13. Available from: http://progressintransplantation.com/ doi/abs/10.7182/prtr.15.1.0n13660r26g725kj

7. Crowe M. CCAT form v1.4. 2013;4(November):4-5.

8. Berger VW, Alperson SY. A general framework for the evaluation of clinical trial quality. Rev Recent Clin Trials [Internet]. 2009;4(2):79-88. Available from: http://www. pubmedcentral.nih.gov/articlerender.fcgi?artid=26949 51\&tool=pmcentrez\&rendertype=abstract

9. PRISMA Statement. PRISMA Flowchart Diagram [Internet]. 2015 [cited 2018 May 9]. Available from: http://prisma-statement.org/prismastatement/ flowdiagram.aspx
10. Murnane PM, Brown ER, Donnell D, Coley RY, Mugo N, Mujugira A, et al. Estimating Efficacy in a Randomized Trial With Product Nonadherence: Application of Multiple Methods to a Trial of Preexposure Prophylaxis for HIV Prevention. Am J Epidemiol. 2015;182(10):848-56.

11. Carballo-Diéguez A, Balán IC, Brown W, Giguere R, Dolezal C, Leu CS, et al. High levels of adherence to a rectal microbicide gel and to oral Pre-Exposure Prophylaxis (PrEP) achieved in MTN-017 among men who have sex with men (MSM) and transgender women. PLoS One. 2017;12(7):1-17.

12. Kibengo FM, Ruzagira E, Katende D, Bwanika AN, Bahemuka U, Haberer JE, et al. Safety, Adherence and Acceptability of Intermittent Tenofovir/Emtricitabine as HIV Pre-Exposure Prophylaxis (PrEP) among HIV-Uninfected Ugandan Volunteers Living in HIVSerodiscordant Relationships: A Randomized, Clinical Trial. PLoS One. 2013;8(9):1-10.

13. Mayer KH, Safren SA, Elsesser SA, Psaros C, Tinsley JP, Marzinke M, et al. Optimizing Pre-Exposure Antiretroviral Prophylaxis Adherence in Men Who Have Sex with Men: Results of a Pilot Randomized Controlled Trial of "Life-Steps for PrEP.” AIDS Behav. 2017;21(5):1350-60.

14. Shrestha R, Altice FL, Karki P, Copenhaver MM. Integrated Bio-behavioral Approach to Improve Adherence to Pre-exposure Prophylaxis and Reduce HIV Risk in People Who Use Drugs: A Pilot Feasibility Study. AIDS Behav. 2018;(123456789):1-10.

15. Pool R, Montgomery CM, Morar NS, Mweemba O, Ssali A, Gafos M, et al. Assessing the accuracy of adherence and sexual behaviour data in the MDP301 Vaginal microbicides trial using a mixed methods and triangulation model. PLoS One. 2010;5(7). 